\title{
MOUSE $\alpha$-AMYLASE SYNTHESIZED BY SACCHAROMYCES CEREVISIAE IS RELEASED INTO THE CULTURE MEDIUM
}

\author{
by \\ KARL KRISTIAN THOMSEN
}

Department of Physiology, Carlsberg Laboratory

Gamle Carlsberg Vej 10, DK-2500, Copenhagen Valby

Keywords: Heterologous gene product, excretion

\begin{abstract}
A cDNA segment complementary to the mouse salivary amylase messenger RNA has been inserted into the yeast expression vector pMA56 behind the promoter of the gene encoding the alcohol dehydrogenase I of yeast. Yeast transformants containing plasmids with the normal orientation of the promoter and the mouse $\alpha$-amylase cDNA gene produce amylase and release the enzyme in free form into the medium. In one litre cultures with a final cell density of $2 \cdot 10^{7}$ cells $\cdot \mathrm{ml}^{-1} 75 \mu \mathrm{g}$ of amylase is found corresponding to $0.1 \%$ of the cell protein. It has been estimated that almost $90 \%$ of the amylase synthesized by the cells is excreted. A handy plate assay for colonies excreting $\alpha$-amylase is described.
\end{abstract}

\section{INTRODUCTION}

Mouse salivary $\alpha$-amylase is released to the environment from the site of synthesis in the acinar cells of the parotid gland. This enzyme hydrolyzes $\alpha$-1,4-glucosidic bonds in polysaccharides, such as starch. A cDNA of the complete mouse salivary amylase mRNA has been cloned (15). Since amylase is a secreted enzyme which can be detected by a simple assay, it is well suited for studies on the release of a foreign gene product synthesized in yeast.

The expression of foreign genes from higher eukaryotes in yeast, usually depends on the presence of a yeast promoter sequence. The yeast gene $A D C I$ codes for the the enzyme alcohol dehydrogenase I which catalyzes the reduction of acetaldehyde to ethanol. This enzymatic step is utilized when yeast is grown on glucose or other fermentable carbon sources. The $A D C I$ gene has been isolated, and the coding region together with more than 700 base pairs of the 5 ' flanking region have been sequenced (1). The promoter region is contained on a $1.5 \mathrm{~kb}$ BamHI fragment, that has the ability to direct the expression of foreign genes in yeast when they are inserted behind this promoter. In this way both human leukocyte interferon and hepatitis B virus surface antigen have been synthesized by yeast $(1,17)$.

In the present paper the insertion of mouse amylase cDNA into a yeast expression vector containing the $A D C I$ promoter is described. It is found that yeast cells with this plasmid synthesize $\alpha$-amylase and excrete the enzyme into the culture medium. 


\section{MATERIALS AND METHODS}

\subsection{Strains and media}

The bacterial strain used was ED8654 (supE, supF, $h s d R^{-} M^{+} S^{+}$, met $t^{-} \operatorname{trpR}$ ) (12), and the Saccharomyces cerevisiae strain DB746 (MAT $\alpha$ his 301 leu2-3 leu2-111 ura3-52 trp1 289).

Bacteria were grown in LB medium (13) supplied with $50 \mu \mathrm{g} \cdot \mathrm{ml}^{-1}$ of ampicillin or 25 $\mu \mathrm{g} \cdot \mathrm{ml}^{-1}$ of tetracycline, when appropriate. Media for yeast have been described (14).

\subsection{Plasmids}

The plasmid pMSal04 (15) which is pBR322 with a full length mouse salivary $\alpha$-amylase cDNA inserted in the PstI site was obtained from Dr. Peter K. Wellauer, Swiss Institute for Experimental Cancer Research, Epalinges, Switzerland. The yeast expression vector, pMA56, was received from Dr. B. HALL, University of Washington, Seattle, USA. This vector contains most of pBR322 including the ampicillin resistance gene and the origin of replication. It also contains the yeast $A D C I$ promoter, a yeast $T R P I$ gene and an origin of replication from the yeast $2 \mu$ circular plasmid. The expression vector has a unique EcoRI site downstream from the $A D C I$ promoter (17).

\subsection{Enzymes and chemicals}

Restriction endonucleases, T4 DNA ligase, alkaline phosphatase, polynucleotide kinase, S-adenosylmethionine, nucleoside tri-phosphates and spermidine were from Boehringer Mannheim. EcoRI linker, Bal31 exonuclease, T4 DNA polymerase and EcoRI methylase were from Bethesda Research Laboratories. Epoxy-activated Sepharose 6B was purchased from Pharmacia Fine Chemicals and cycloheptaamylose (Schardinger $\beta$-dextrin) from Sigma Chemical Company. Soluble starch (after Zulkowsky) was from Merck. Authentic mouse salivary $\alpha$-amylase was obtained from Dr. J.P. HJORTH, Department of Molecular Biology, University of Aarhus, Denmark.

\subsection{DNA-purification}

Plasmid DNA was prepared from E. coli by the alkaline lysis method of BIRNBOIM and DOLY (2), which for large scale preparations was followed by $\mathrm{CsCl}$ equilibrium centrifugation. The
PstI restriction fragment of pMSa104 containing the coding sequence for mouse $\alpha$-amylase was isolated from agarose gels by electroelution into dialysis tubing. The cDNA solution was extracted with an equal volume of phenol and subsequently concentrated by repeated extractions with equal volumes of $n$-butanol, followed by ethanol precipitation.

\subsection{Construction of plasmids expressing $\alpha$-amylase}

The strategy employed in the construction of plasmids with the potential of expressing mouse $\alpha$-amylase in yeast is outlined in Figure 1. The plasmid pMSal04 was digested with PstI. This enzyme cuts out the cDNA insert as two fragments of $1630 \mathrm{bp}$ and $32 \mathrm{bp}$. The $1630 \mathrm{bp}$ fragment contains the entire amylase coding sequence plus 62 untranslated base pairs upstream from the initiation codon (3). The EcoRI sites of the purified fragment were methylated as described by Maniatis et al. (10). The PstI ends were converted to blunt ends by the following procedure. Ten $\mu \mathrm{g}$ of the cDNA fragment were dissolved in $100 \mu$ l buffer ( $20 \mathrm{~mm}$-Tris- $\mathrm{HCl}, \mathrm{pH}$ $8.0,12 \mathrm{~mm}-\mathrm{CaCl}_{2}, 12 \mathrm{~mm}-\mathrm{MgCl}_{2}, 60 \mathrm{~mm}-\mathrm{NaCl}, 1$ mM-EDTA). The reaction mixture was warmed to $30{ }^{\circ} \mathrm{C}$ and 0.1 unit of Bal31 exonuclease was added. Samples of $25 \mu \mathrm{l}$ were withdrawn after $0.5,1.0,1.5$ and 2.0 minutes and immediately mixed with $25 \mu$ l of 25 mM-EDTA, $1 \%$ sodium dodecyl sulfate. This regimen was followed to obtain cDNA fragments of different length. The four aliquots were pooled and extracted with 200 $\mu l$ of phenol. The aqueous phase was reextracted with an equal volume of chloroform-isoamylalcohol (25:1) and ethanol precipitated. To increase the yield of molecules with blunt ends, the Bal31 treated DNA was incubated with 10 units of T4 DNA polymerase in $33 \mathrm{~mm}$-Tris-acetate ( $\mathrm{pH} 7.9), 66-\mathrm{mm}$ potassium acetate, $10 \mathrm{~mm}$ magnesium acetate, $0.5 \mathrm{~mm}$-dithiothreitol and $100 \mu \mathrm{m}$ of dATP, dCTP, dGTP and TTP. The reaction was carried out at $37^{\circ} \mathrm{C}$ for 30 minutes and stopped by extraction with phenol and chloroform-isoamylalcohol followed by ethanol precipitation.

In order to prepare EcoRI linker for ligation 5 $\mu \mathrm{g}$ of linker were incubated with 20 units of polynucleotide kinase in $66 \mathrm{~mm}-\mathrm{Tris}-\mathrm{HCl}(\mathrm{pH} \mathrm{7.6)}$, 
A

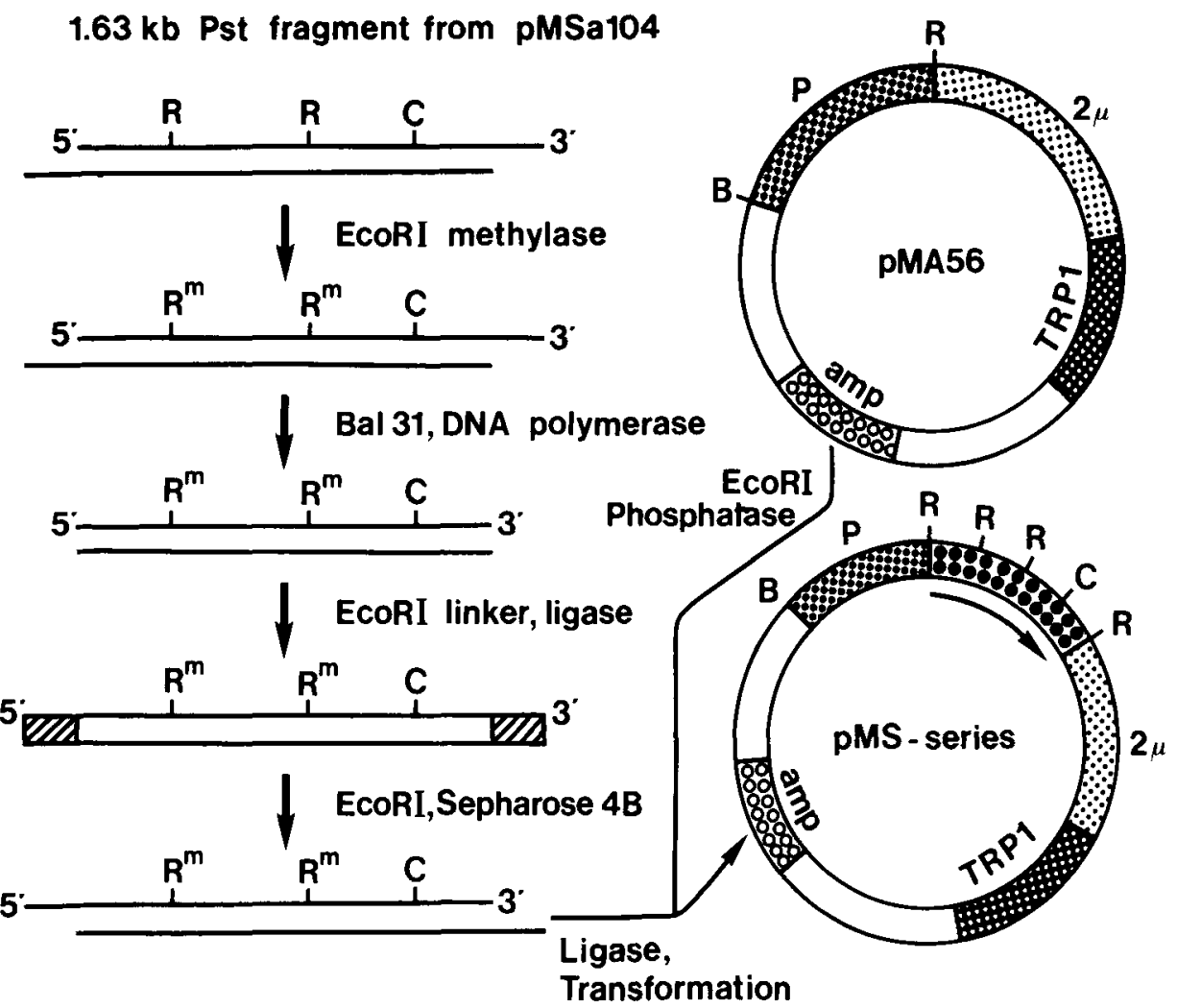

B

ADCI promoter

Amylase $5^{*}$ non-translated region

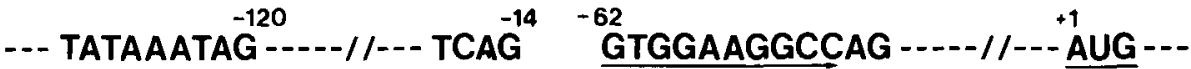

$$
\begin{aligned}
& \text { Bal } 31 \text { digestion }
\end{aligned}
$$

Figure I. A: Construction of $\alpha$-amylase expression plasmids. The plasmid pMSa 104 was digested with PstI and the fragment containing the $\alpha$-amylase coding region and most of the flanking regions was isolated by preparative agarose gel electrophoresis. The EcoRI sites of the purified fragment were methylated, and in order to convert the PstI ends to blunt ends the fragment was given a mild treatment with Bal31 exonuclease followed by incubation with T4 DNA polymerase. Phosphorylated EcoRI oligonucleotide linker were then ligated to the blunt ended cDNA fragment, using T4 DNA ligase. Excess linker was digested with EcoRI restriction endonuclease and separated from the cDNA fragment on a Sepharose $4 \mathrm{~B}$ column. Amylase cDNA fragments with EcoRI ends were ligated into EcoRI digested and phosphatase treated pMA56. E. coli, strain ED8654, was transformed with the ligation mixture, and plasmid DNA from individual transformants was screened for size by agarose gel electrophoresis. $\mathrm{B}=\mathrm{BamHI}$ site, $\mathrm{C}=\mathrm{ClaI}$ site, $\mathrm{R}=$ EcoRI site, $\mathrm{R}^{\mathrm{m}}=$ methylated EcoRI site, $\mathrm{P}=$ promoter. Technical details are described in section 2.5 . $\mathrm{B}$ : Joining amylase cDNA fragments to the $A D C I$ promoter. Bal31 resected cDNA fragments were joined to the $A D C I$ promoter using an EcoRI linker. Sequence data are from BENNETZEN and HALL (1) and HAGENBUC'HLE et al. (3). 
$10 \mathrm{~mm}-\mathrm{MgCl}_{2}, 1 \mathrm{~mm}$-spermidine, $1 \mathrm{~mm}$-ATP, 15 mM-dithiothreitol and $0.4 \mathrm{mg} \cdot \mathrm{ml}^{-1}$ of bovin serum albumin in $50 \mu \mathrm{l}$. After half an hour at 37 ${ }^{\circ} \mathrm{C} 10$ units of fresh enzyme were added, and the incubation continued for another 30 minutes. Half a microgram of the phosphorylated linker was mixed with approximately $3 \mu \mathrm{g}$ of blunt-ended cDNA dissolved in the phosphorylation buffer and 4.5 units of T4 DNA ligase in a total volume of $12.5 \mu \mathrm{l}$. Thus the linker was present in a $30-35$ fold molar excess $(8 \mu \mathrm{M}$ to $0.25 \mu \mathrm{M})$. The reaction was left at $14^{\circ} \mathrm{C}$ overnight. After extraction with phenol and chloroform-isoamylalcohol followed by ethanol precipitation the ligation mixture was dissolved in $50 \mathrm{~mm}$-Tris$\mathrm{HCl}$ (pH 7.5), 100 mм- $\mathrm{NaCl}, 10$ mM- $\mathrm{MgCl}_{2}, 1$ mM-dithiothreitol and incubated with 250 units of EcoRI for one hour at $37^{\circ} \mathrm{C}$. The reaction mixture was extracted with equal volumes of phenol and chloroform-isoamylalcohol. The aqueous phase was adjusted to $300 \mathrm{~mm}-\mathrm{NaCl}$ and the free oligonucleotide linker was separated from the cDNA fragment on a $5 \mathrm{ml}$ Sepharose 4B column. Fractions of $300 \mu \mathrm{l}$ were collected and those containing the cDNA fragment were identified by agarose gel electrophoresis. Fractions containing the cDNA but no free oligonucleotide linker were pooled, precipitated from $70 \%$ ethanol and redissolved in $20 \mu$ l water.

The yeast expression plasmid, pMA56, was digested with EcoRI, and in order to reduce recircularization of the vector it was treated with alkaline phosphatase in $50 \mathrm{mM}$-Tris- $\mathrm{HCl}(\mathrm{pH} 8.0)$, $0.1 \mathrm{~mm}$-EDTA, using one unit of phosphatase per microgram of DNA. After incubation at $25^{\circ} \mathrm{C}$ for 30 minutes a similar amount of enzyme was added and the reaction was allowed to take place for another 30 minutes. The phosphatase reaction was stopped by extraction with equal volumes of phenol and chloroform-isoamylalcohol followed by ethanol precipitation. The phosphatase treated plasmid was dissolved in water, and approximately $0.2 \mu \mathrm{g}$ was mixed with $5 \mu \mathrm{l}$ of the CDNA solution and 1 unit of T4 DNA ligase in $20 \mathrm{~mm}$-Tris- $\mathrm{HCl}(\mathrm{pH} 7: 6), 10 \mathrm{~mm}-\mathrm{MgCl}_{2}, 10$ mM-dithiothreitol and $0.6 \mathrm{mM}$-ATP. Incubation was overnight at $14{ }^{\circ} \mathrm{C}$ in a total volume of $10 \mu \mathrm{l}$ and without further treatment the ligation mixture was used to transform E. coli strain ED8654 to ampicillin resistance.

\subsection{Transformation}

E. coli cells were grown and prepared for transformation as described by LEDERBERG and CoHN (8). The competent cells were resuspended in $100 \mathrm{mM}-\mathrm{CaCl}_{2}$ containing $12 \%$ glycerol, frozen in liquid nitrogen and stored at $-80^{\circ} \mathrm{C}$. For transformation $0.2 \mathrm{ml}$ of slowly thawed competent cells, $0.1 \mathrm{ml}$ of buffer (10 mM-Tris- $\mathrm{HCl}, \mathrm{pH} 7.5$, $10 \mathrm{~mm}-\mathrm{CaCl}_{2}, 10 \mathrm{~mm}-\mathrm{MgCl}_{2}$ ) and the ligation mixture were combined in a sterile Eppendorf tube. The mixture was left on ice for 30 minutes and transferred to a $25^{\circ} \mathrm{C}$ waterbath. After 20 minutes $0.5 \mathrm{ml}$ of $\mathrm{LB}$ medium was added and the tube was shaken at $37^{\circ} \mathrm{C}$ for $30-45$ minutes before plating on LB solid medium containing ampicillin. Yeast cells were transformed according to the method of ITo et al. (6) using lithium nitrate to induce competence.

\subsection{Amylase assays}

Plate assay. Individual yeast colonies were screened for the ability to express the amylase gene carried by the plasmid and to secrete active amylase to the surrounding medium. This was done by plating the colonies on SC medium without the auxotrophic requirement, tryptophan, but containing $0.1 \%$ soluble starch. The plates were incubated overnight at $30^{\circ} \mathrm{C}$ and then stained with $\mathrm{I}_{2}-\mathrm{KI}$ in $\mathrm{H}_{2} \mathrm{O}$ (1:2:300). Colonies synthesizing and secreting amylase were surrounded by a clear zone - a halo - on the dark iodine stained background.

Determination of relative amylase activity in solution. The assay used to determine the relative activity of $\alpha$-amylase in solution was also based on the reaction of iodine with starch. In a total volume of $1.5 \mathrm{ml}$ different amounts of an amylase solution were mixed with $50 \mu \mathrm{l}$ of a $1 \%$ starch solution. After an appropriate incubation period, usually $40-60$ minutes, $10 \mu$ lof $\mathrm{I}_{2}-\mathrm{KI}_{-}-\mathrm{H}_{2} \mathrm{O}$ were added and the extent of starch degradation was judged by visual inspection. By this titration the relative amount of amylase activity in different solutions could be estimated. One unit is defined as the amount of amylase activity which, by the degradation of starch reduces the color intensity of an iodine stained solution to half of the intensity of a similar solution without enzyme after an incubation period of 45 minutes at room temperature. 


\subsection{Purification of $\alpha$-amylase}

An $\alpha$-amylase affinity column was prepared essentially as described by VRETBLAD (18) and Silvnavich and Hill (16). Cycloheptaamylose was coupled to epoxy-activated Sepharose 6B in $0.1 \mathrm{M}-\mathrm{NaOH}$. The coupling reaction was carried out at $37^{\circ} \mathrm{C}$ for 20 hours. The gel was then washed at room temperature with water, glucose ( 25 $\left.\mathrm{mg} \cdot \mathrm{ml}^{-1}\right)$, water and $50 \mathrm{~mm}$-sodium acetate $(\mathrm{pH}$ 4.8). Before use the gel was packed in a column and equilibrated with $50 \mathrm{~mm}$-sodium acetate, (pH 5.5), $1 \mathrm{~mm}-\mathrm{CaCl}_{2}$.

One litre of supernatant from a culture of yeast cells harboring a chimeric plasmid directing the synthesis of $\alpha$-amylase was dialysed against 5 litres of $50 \mathrm{~mm}$-sodium acetate (pH 5.5), $1 \mathrm{~mm}$ $\mathrm{CaCl}_{2}$ overnight and then passed through the affinity column at a flow rate of $40-50 \mathrm{ml}$ per hour. The column was washed with 50 mm-sodium acetate ( $\mathrm{pH} 5.5), 1 \mathrm{~mm}-\mathrm{CaCl}_{2}$ until the absorption at $280 \mathrm{~nm}$ was essentially zero. The $\alpha$-amylase bound to the column was eluted using the same buffer supplied with $8 \mathrm{mg} \cdot \mathrm{ml}^{-1}$ of cycloheptaamylose.

\subsection{Determination of protein}

The concentration of protein was determined using a protein assay kit from Bio-Rad Laboratories following the conditions recommended by the manufacturer. Egg albumin was used as standard.

\subsection{Preparation of cell-free extract}

Transformed yeast cells were grown in 1 litre of SC medium without tryptophan and collected by centrifugation at $5000 \mathrm{rpm}$. for 10 minutes in a Sorvall GS3 rotor, washed with $50 \mathrm{~mm}$-sodium acetate $(\mathrm{pH} 5.5) 1 \mathrm{~mm}-\mathrm{CaCl}_{2}$ and recentrifuged. The cells were resuspended in $5 \mathrm{ml}$ of the same buffer. Fifteen $\mathrm{ml}$ of chilled glass beads were added and the cells broken open by shaking in a Brown MSK homogenizer four times for 20 seconds with chilling on ice between the cycles. The homogenate was cleared by centrifugation at $20,000 \mathrm{rpm}$. for 15 minutes in a Sorvall SS-34 rotor and the cleared extract was immediately frozen at $-20^{\circ} \mathrm{C}$. All operations were carried out in the cold.

\subsection{Gel electrophoresis}

Electrophoresis of DNA was in $0.8 \%$ agarose gels in $40 \mathrm{~mm}$-Tris base, $20 \mathrm{~mm}$-acetic acid, 2 mM-Na $\mathrm{NDDTA}_{2} \mathrm{pH} 8.5$ with ethidium bromide $\left(0.5 \mu \mathrm{g} \cdot \mathrm{ml}^{-1}\right)$. Proteins were analyzed on denaturing polyacrylamide gels (11-15\%) as described by MACHOLD et al. (9).

\subsection{Containment}

All experiments involving recombinant DNA were carried out under Pl laboratory conditions and waste containing biological material was destroyed by autoclaving.

\section{RESULTS}

\subsection{Construction of plasmids directing expression of mouse $\alpha$-amylase in yeast}

Plasmids with mouse $\alpha$-amylase cDNA inserted behind the $A D C I$ promoter from yeast, and thus with the potential of $\alpha$-amylase expression, were constructed as outlined in Figure 1 and as described in detail in section 2.5. Among the obtained E. coli transformants 96 were analyzed for the presence of a cDNA insert by small-scale preparations of plasmid DNA: The plasmids were subjected to agarose gel electrophoresis together with the vector, pMA56, and an increased molecular weight of plasmid DNA isolated from a transformant was taken to mean that a particular plasmid carried a cDNA insert. Among the 96 transformants analyzed, 40 were found to carry a plasmid containing an amylase cDNA insert, and since Bal31 not only leaves blunt ends, but also slowly degrades double stranded DNA from the ends it was expected that individual transformants carried plasmids with cDNA inserts slightly different in length.

\subsection{Orientation of cDNA inserts}

Plasmid DNA was prepared from the forty transformants harboring plasmids with cDNA inserts using the alkaline lysis method (2) followed by $\mathrm{CsCl}$ equilibrium centrifugation. As indicated in Figure 1 the parental plasmid has a single recognition site for the enzyme BamHI, but no ClaI sites. The cDNA insert, however, has an asymmetrically located ClaI site, but no recognition sites for BamHI. A double digest with these two enzymes should therefore establish the orientation of the amylase cDNA insert relative 


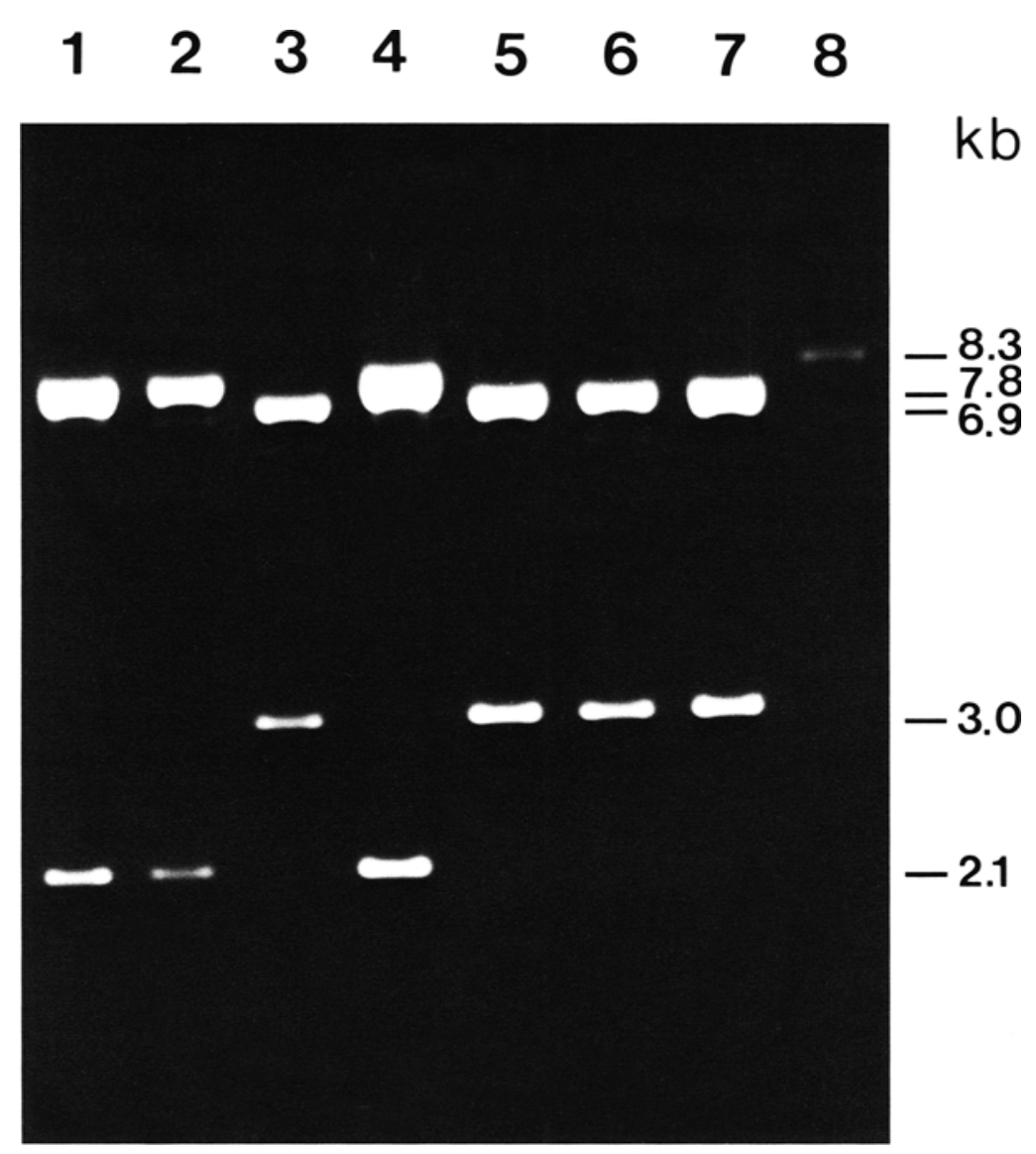

Figure 2. Analysis of BamHI-ClaI restriction endonuclease digested plasmids. The orientation of insertion of amylase cDNA was determined by double digests of the plasmid DNA with BamHI and Clal. The vector itself has a single recognition site for BamHI, but has no ClaI sites whereas amylase cDNA has a recognition site for ClaI at position 1285 but no BamHI sites. The figure shows an electrophoretic analysis of BamHI-ClaI double digests of plasmids with amylase cDNA inserts. Lanes 3,5,6 and 7 are plasmids with the insert in the correct orientation while lanes 1,2 and 4 show digests of plasmids carrying the insert in the opposite orientation. Lane 8 is pMA56 digested with BamHI and Clal.

to the $A D C I$ promoter. If the cDNA is inserted in the orientation suitable for expression, fragments of about $6.9 \mathrm{~kb}$ and $3.0 \mathrm{~kb}$ are expected. With the opposite orientation the fragments would be $7.8 \mathrm{~kb}$ and $2.1 \mathrm{~kb}$ in size. In Figure 2 the result of an electrophoretic analysis of plasmids digested with BamHI and ClaI is shown together with an identical digest of pMA56. Two classes of plasmid molecules are present. The plasmids in lanes $3,5,6$, and 7 give rise to fragments with the molecular weights which are expected when the amylase cDNA is inserted in the correct orientation, while the plasmids in lates 1,2 and 4 display the fragment pattern for cDNA inserted with the opposite orientation. It may be worth pointing out that possible differences in the length among the cDNA inserts resulting from the treatment with Bal 31 exonuclease cannot be detected with the resolution of this gel. Among the forty amylase cDNA carrying plasmids isolated, twenty had the cDNA inserted in the correct orientation relative to the $A D C I$ promoter. 


\subsection{Screening for expression of $\alpha$-amylase in} yeast

The amylase cDNA fragment isolated from the plasmid pMSa104 contained the entire $\alpha$-amylase coding sequence, including the code for the signal peptide, which in mouse salivary $\alpha$-amylase is 15 amino acid residues long (7). It was considered that a mouse signal peptide might be able to mediate secretion in yeast. Therefore the plate assay described in section 2.7 was chosen to screen for expression and secretion of amylase. Plasmids carrying the cDNA insert in the correct orientation were used to transform strain DB746 of yeast. This strain carries a mutation in the TRPI gene, which disables it to grow on medium without tryptophan. Since the mutation can be complemented by the $T R P I$ gene carried in the plasmid transformed cells were selected on SC medium without tryptophan. Individual colonies were transferred to new plates without tryptophan and to similar plates containing $0.1 \%$ soluble starch. In Figure 3 a master plate and a starch containing plate are shown. Both plates have been incubated overnight and each group of three colonies represents one transformation experiment. In the upper row is the non-transformed yeast strain, DB746. which does not grow on medium without tryptophan. The bottom row of three colonies represents cells transformed with the vector, pMA56, with no insert. These colonies are able to grow on medium without tryptophan, but they do not produce haloes. The fifteen colonies in groups of three, between the controls, represent different

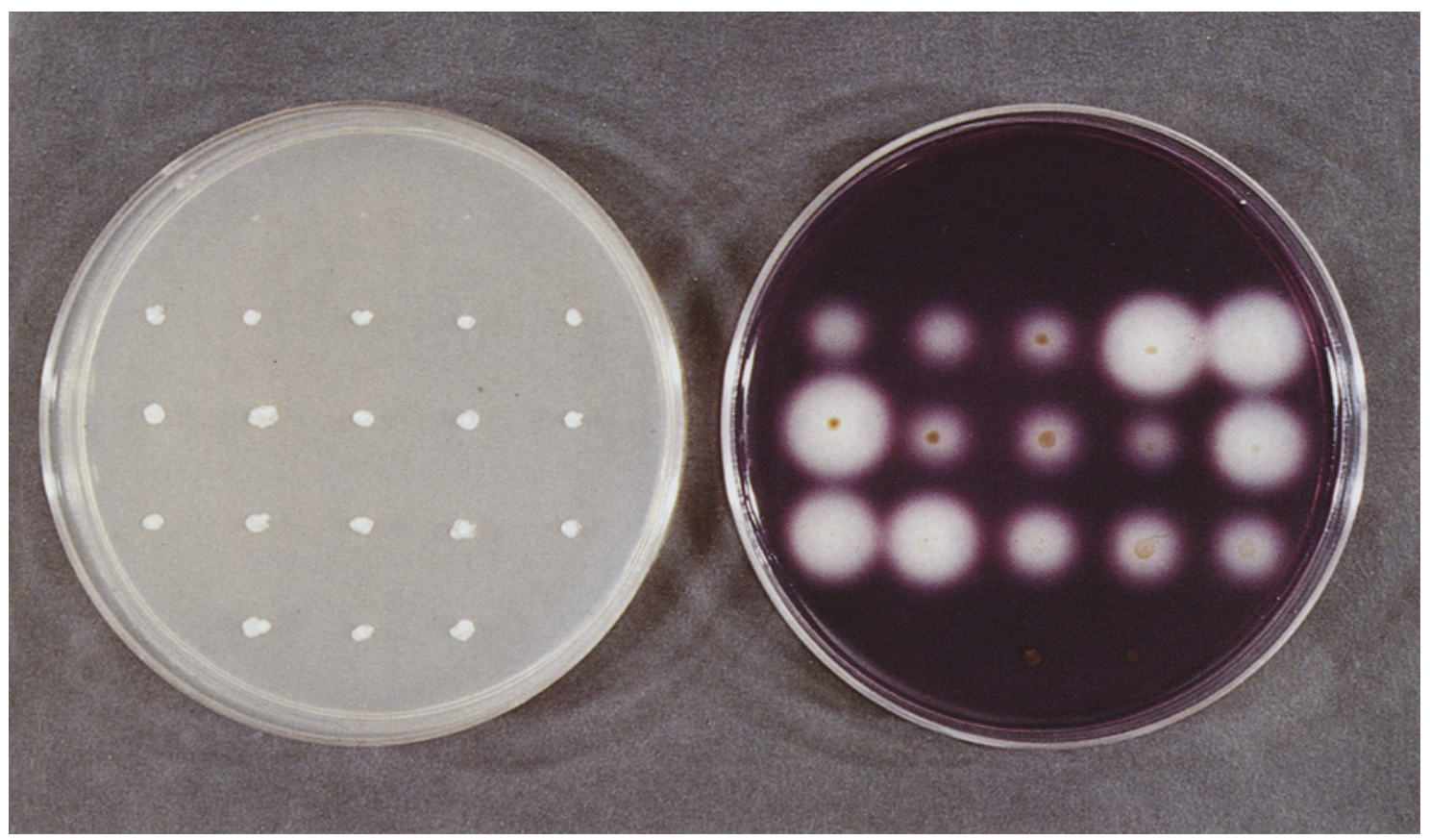

Figure 3. Screening of transformed cells for secretion of $\alpha$-amylase activity. Chimeric plasmids carrying an amylase CDNA insert in the correct orientation relative to the $A D C I$ promoter were used to transform a yeast strain, auxotrophic for tryptophan due to a mutation in the TRPI gene. This mutation is complemented by the functional TRPI gene carried by the plasmid. Colonies from individual transformed cells were transferred to SC medium without tryptophan (left) and to the same medium supplied with $0.1 \%$ soluble starch (right). After incubation overnight the starch containing plates were stained with $\mathrm{I}_{2}-\mathrm{KI}$ and a clear zone on a dark background around a colony shows that this colony produces and excretes amylase. Upper row: Three colonies of the non-transformed recipient strain, DB746. The three middle rows: Colonies derived from individual transformed cells. Each group of three with similar sized haloes originates from a different plasmid preparation used for transformation. The five groups shown may therefore have cDNA inserts of slightly different length. Bottom row: Colonies transformed with the parental plasmid, pMA56. 


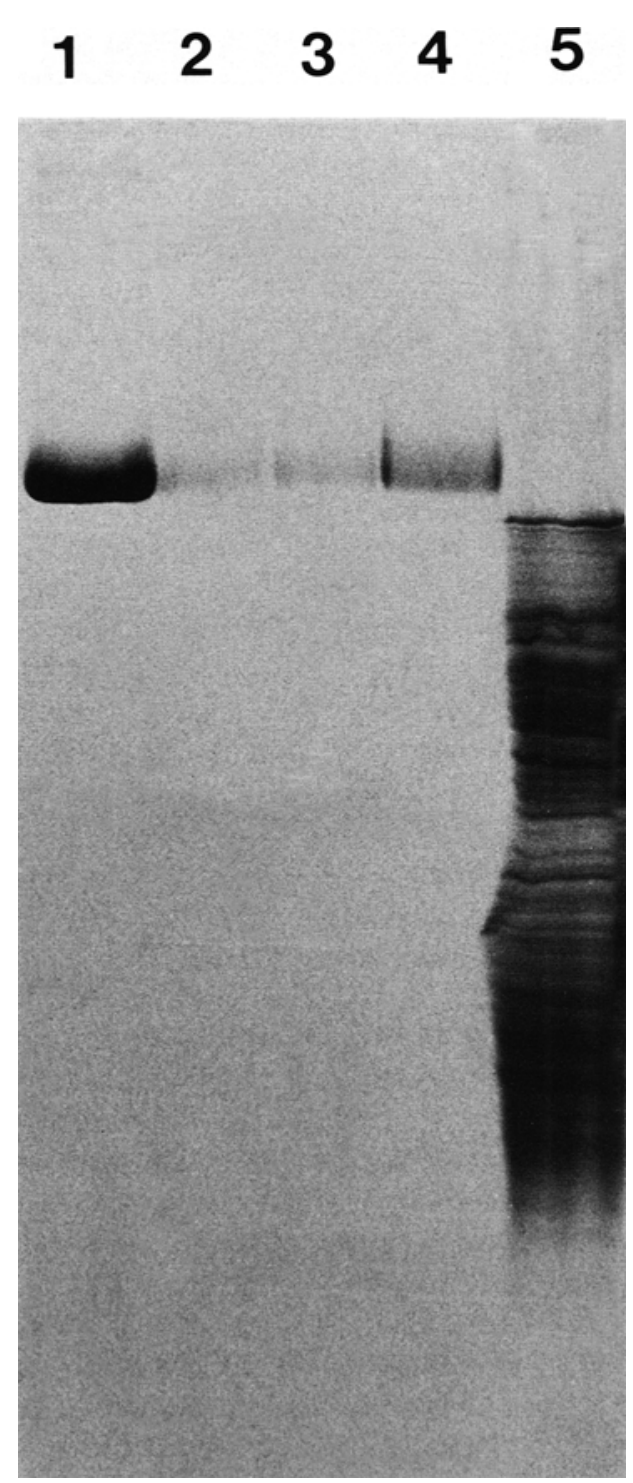

Figure 4. Polyacrylamide gel electrophoresis of purified amylase. Amylase excreted into the medium by a yeast culture harboring an amylase expression plasmid was purified by affinity chromatography and analysed on an 11-15\% polyacrylamide-SDS gel. 1: Native mouse salivary $\alpha$-amylase purified by affinity chromatography. Lanes 2, 3 and 4: Amylase purified from the culture medium after the yeast cells had been sedimented out. Lane 5: Cell-free extract prepared from amylase secreting yeast cells. transformation experiments using five different plasmid preparations. As pointed out earlier, the chimeric plasmids should carry cDNA inserts slightly different in length, due to the initial treatment with Bal31 exonuclease. Transformants obtained from different plasmid preparations might therefore differ in the level of amylase synthesis and/or secretion. The five groups of transformants shown in Figure 3 produce haloes of different size, which apparently is not directly related to the different amounts of yeast biomass transferred to the test plate. Of the twenty plasmid preparations, with the appropriate orientation of the insert to the yeast promoter fifteen gave transformants which were positive in the plate assay. Transformants obtained with plasmids having the amylase sequence in reverse orientation could not degrade starch.

\subsection{Analysis of the secreted product}

A single colony from one of the transformants producing big haloes in the plate assay was used to inocculate $5 \mathrm{ml}$ of SC medium without tryptophan. After incubation overnight this culture was diluted to one litre in the same medium and further shaken for about twenty hours to give $2 \cdot 10^{7}$ cells per $\mathrm{ml}$. The cells were then collected, a cell-free extract prepared, and the amylase activity was measured in both the culture fluid and the cell-free extract. Amylase was purified from the cell culture fluid by affinity chromatography; No amylase activity could be detected in the solution after it had passed through the affinity column.

The purified amylase was lyophylized and analyzed by denaturing polyacrylamide gel electrophoresis together with native mouse salivary amylase and the cell-free extract. The result is shown in Figure 4. Amounts of 5, 10 and $50 \mu$ of a solution of the protein purified from the cell culture medium (lanes 2, 3 and 4, respectively) appear as single bands which co-migrate with the authentic mouse $\alpha$-amylase (lane 1). In the lane in which the cell-free extract has been separated (lane 5) no polypeptides are seen in the corresponding molecular weight region. This comparison argues that most of the amylase is released from the cells. The amount of protein eluted from the affinity column and in that obtained from the cell-free extract was determined (Table 
Table I.

Amylase produced by yeast strain DB746 carrying a pMA56 plasmid with the mouse salivary $\alpha$-amylase insert (pMS12) in a one litre culture. The amount of amylase in the medium is compared with that inside the cells. The protein of the culture fluid was that eluted from an affinity column. One unit of amylase is defined by the $50 \%$ reduction in iodine staining intensity of a standard starch solution (section 2.5).

\begin{tabular}{lccc}
\hline & $\begin{array}{c}\text { Amylase activity } \\
\text { in arbitrary units }\end{array}$ & $\begin{array}{c}\text { Amount of protein } \\
(\mathrm{mg})\end{array}$ & $\begin{array}{c}\text { Amylase activity } \\
\text { per mg of protein }\end{array}$ \\
\hline Culture fluid & 2000 & 0.075 & 26667 \\
Extract of cells & 250 & 75 & 3.3 \\
\hline
\end{tabular}

I). Approximately $75 \mu \mathrm{g}$ of amylase is synthesized and excreted in one litre of yeast culture, corresponding to about $0.1 \%$ of the total cell protein. It is remarkable that almost $90 \%$ of the amylase activity is exported from the cells and into the culture medium.

\section{DISCUSSION}

In the present investigation a series of plasmids were constructed which contain the coding sequence for mouse salivary $\alpha$-amylase and thus have the potential of directing synthesis of this enzyme. Amylase cDNA fragments were inserted in the yeast expression vector pMA56 (17) behind the yeast $A D C I$ promoter at a position corresponding to -14 from the site of initiation of translation of the alcohol dehydrogenase I mRNA (1). Plasmids carrying the cDNA insert in the correct orientation were used to transform a tryptophan auxotrophic yeast strain. Transformants were selected on medium without tryptophan and their ability to synthesize and secrete amylase was examined in a plate assay. In this assay most of the transformants produced haloes due to the degradation of starch in the area around the colony. The haloes produced by individual transformants were different in size. This might be a result of variation in the efficiency of expression of the heterologous gene. However, the structural basis for the observed size variation among haloes has not been established. The presumed sites for initiation of transcription are located at positions -27 and -37 from the initiation codon (1), and the site of insertion is at position -14. The number of 5 ' untranslated nucleotides that can be derived from the $A D C I$ part of the chimeric transcription unit is therefore 13 or 23 , whereas the amylase cDNA may specify from a few and up to about 60 nucleotides of the 5 ' untranslated part of the mRNA, thereby affecting both the length and the base composition of the 5 ' non-translated region. This may very well influence the rate by which translation is initiated for instance due to different ribosome binding efficiencies. In those plasmids that turned out negative in the plate assay, the Bal31 exonuclease digestion may have gone beyond the initiation codon, thus excluding the possibility for proper initiation of translation.

The amylase production of one of the transformants, pMS-12, was analysed in liquid medium (Table I). The amylase secreted into the medium was purified by affinity column chromatography and when analysed on a denaturing polyacrylamide gel it appeared homogeneous, and co-migrated with native mouse salivary amylase. Whether it has the same amino terminal, i. e. if it is processed exactly as the native mouse salivary amylase, has not yet been determined.

When amylase was purified from yeast culture medium all the amylase activity was bound by the column. The amount of amylase protein that could be purified from one liter of medium was about $75 \mu \mathrm{g}$, roughly corresponding to $0.1 \%$ of total yeast protein.

VALENZUELA et al. (17) used the same plasmid for expression of hepatitis B virus surface antigen in yeast and estimated the amount of the heterologous gene product to be 10-25 $\mu \mathrm{g}$ per liter of yeast culture, but the product could only be detected in cell-free extracts, and not in the culture medium. HITZEMAN et al. (4) used a similar plasmid, also containing the $A D C I$ promoter 
from yeast, to direct the expression of human leukocyte interferon $\mathrm{D}$ (LeIF D). From their data it can be calculated that up to $30 \mu \mathrm{g}$ of active interferon was synthesised per liter of culture. In a different study HitZEMAN et al. (5) used a plasmid containing both 5' and 3' flanking regions of the yeast $P G K$ gene, (3-phosphoglycerate kinase) and inserted cDNAs encoding different human interferons between the $P G K$ 5' and 3' flanking regions. When cDNA encoding LeIF A or LeIF $\mathrm{D}$ was inserted the heterologous products constituted up to $1 \%$ of total yeast protein, but only low levels or no secretion at all was observed. Transport across the plasmalemma of up to $20 \%$ of the total interferon activity was achieved when a cDNA encoding pre-LeIF $\gamma$ was inserted into the vector but in these experiments the amount of the heterologous gene product was reduced to about $0.01 \%$ of total yeast protein. The amount of secreted product was measured after cell wall digestion.

In a recent publication MELLOR et al. (11) report on the synthesis of calf chymosin by yeast. Like Hitzeman et al. (5) they constructed a vector containing the 5 ' and 3 ' flanking regions of the yeast $P G K$ gene. When inserted into this vector a prochymosin cDNA directed the synthesis of up to $5 \%$ of total cellular protein. None of the product, however, was released from the cells.

In the present paper it is shown that when preamylase cDNA is inserted behind the yeast $A D C I$ promoter it can direct the synthesis of about $0.1 \%$ of total cell protein as amylase. This amount is similar to that obtained with other heterologous genes placed under the control of the yeast $A D C I$ promoter, but in contrast to other gene products studied almost $90 \%$ of the amylase activity is secreted and released in free form into the culture medium.

It should be possible to place the amylase coding sequence under control of a more efficient promoter and thereby increase the total amount of amylase activity in the culture medium. In terms of practical applications this might enable yeast to utilize high molecular weight carbon sources.

\section{ACKNOWLEDGEMENTS}

KARINA BOSERUP is thanked for excellent technical assistance and M.C. KIELLAND-BraNDT,
J.G.L. PeTERSEN and D. von WeTtSTEIn for critically reading the manuscript. The gift of plasmid pMSal04 from P.K. Wellauer and of pMA56 from B.D. HALL is highly appreciated. J.P. HJORTH is thanked for authenthic mouse salivary amylase. This work was supported by a grant no. 1982 - 133/001 - 82.112 from Teknologistyrelsen of the Ministry of Industry to D. vON WeTtSTEIN and M.C. KIELLAND-BrandT.

\section{REFERENCES}

1. Bennetzen, J.L. \& B.D. Hall: The primary structure of the Saccharomyces cerevisiae gene for alcohol dehydrogenase I. J. Biol. Chem. 257 , 3018-3025 (1982)

2. Birnioim, H.C. \& J. Doly: A rapid alkaline extraction procedure for screening recombinant plasmid DNA. Nucl. Acids Res. 7, 1513-1523 (1979)

3. Hagenduchle, O., R. Bovey \& R.A. Young: Tissue-specific expression of mouse $\alpha$-amylase genes: Nucleotide sequence of isoenzyme mRNAs from pancreas and salivary gland. Cell. 21, 179-187 (1980)

4. Hitzeman, R.A., F.E. Hagie, H.L. Levine, D.V. GoEDDEL, G. AMMERER \& B.D. HaLL: Expression of a human gene for interferon in yeast. Nature 293, 717-722 (1981)

5. Hitzeman, R.A., D.W. Leung, L.J. Perry, W.J. Kohr, F.E. Hagie, C.Y. Chen, J.M. Lugovor, A. SinGH, H.L. LeVine, R. WeTZEL \& D.V. GoedDEL: Expression, processing and secretion of heterologous gene products by yeast. Rec. Adv. Yeast Mol. Biol. 1, 173-190 (1982)

6. Ito, H., Y. Fukuda, K. Murata \& A. Kimura: Transformation of intact yeast cells treated with alkali cations. J. Bacteriol. 153, 163-168 (1983)

7. Karn, R.C., T.E. Petersen, J.P. HJorth, J.T. NIELSEN \& P. ROEPSTORFF: Characterization of the amino termini of mouse salivary and pancreatic amylases. FEBS Lett. 126, 292-296 (1981)

8. Lederberg, E.M. \& S.N. Cohn: Transformation of Salmonella typhimurium by plasmid deoxyribonucleic acid. J. Bacteriol. 119, 1072-1074 (1974)

9. Machold, O., D.J. Simpson \& B.L. Møller: Chlorophyll-proteins of thylakoids from wildtype and mutants of barley (Hordeum vulgare L.). Carlsberg Res. Commun. 44, 235-254 (1979) 
10. Maniatis, T., R.C. Hardison, E. Lacy, J. Lauer, C. O'Connell, D. Quon, G.K. Sim \& A. EFSTRATIADIS: The isolation of structural genes from libraries of eukaryotic DNA. Cell 15, 687701 (1978)

11. Mellor, J., M.J. Dobson, M.A. Roberts, M.F. Tuite, J.S. EmTage, S. White, P.A. Lowe, T. PATEL, A.J. Kingsman \& S.M. Kungsman: Efficient synthesis of enzymatically active calf chymosin in Saccharomyces cerevisiae. Gene 24, 1-14 (1983)

12. Murray, N.E., W.J. Brammar \& K. Murray: Lambdoid phages that simplify the recovery of in vitro recombinants. Mol. Gen. Genet. 150, 53-61 (1977)

13. Petersen, J.G.L., S. Holmberg, T. NilssonTILLGREN \& M.C. KJelLand-Brandt: Molecular cloning and characterization of the threonine deaminase (ILVI) gene of Saccharomyces cerevisiae. Carlsberg Res. Commun. 48, 149-159 (1983)
14. Petersen, J.G.L., M.C. Kielland-Brandt, S. Holmberg \& T. Nilsson-Tillgren: Mutational analysis of isoleucine-valine biosynthesis in Saccharomyces cerevisiae. Mapping of ilv2 and ilv5. Carlsberg Res. Commun. 48, 21-34 (1983)

15. Schibler, U., M. Tosi, A.-C. Pittet, L. Fabiani \& P.K. Wellauer: Tissue-specific expression of mouse $\alpha$-amylase genes. J. Mol. Biol. 142, 93-116 (1980)

16. Silvanovich, M.P. \& R.D. Hill: Affinity chromatography of cereal $\alpha$-amylase. Anal. Biochem. 73, 430-433 (1976)

17. Valenzuela, P., A. Medina, W.J. Rutter, G. AMMERER \& B.D. HALl: Synthesis and assembly of hepatitis $B$ virus surface antigen particles in yeast. Nature 298, 347-350 (1982)

18. VRETBLAD, P.: Immobilization of ligands for biospecific affinity chromatography via their hydroxyl groups. The cyclohexaamylose- $\beta$ amylase system. FEBS Letters 47, 86-89 (1974) 